\title{
Influence of day temperature and salt concentration on the incidence of sponginess in radish tubers (Raphanus sativus L.)
}

\author{
G. Heij' and J. Kobryn' ${ }^{2}$ \\ ${ }^{1}$ Glasshouse Crops Research Station, P.O. Box 8, NL 2670 AA Naaldwijk, Ne- \\ therlands \\ ${ }^{2}$ Agricultural University, Department of Vegetable Crops and Medicinal Plants, \\ Warszawa, Poland
}

Received 12 January 1988; accepted 19 April 1988

Key words: radish, sponginess, tuber quality

\begin{abstract}
Sponginess in radish tubers, Raphanus sativus L. var. radicula Pers., cv. Novired, was studied in two pot experiments at different EC levels of the nutrient solution applied and at two daytime temperature treatments. Increased EC and a low daytime temperature reduced the incidence of sponginess.
\end{abstract}

\section{Introduction}

Sponginess of radish tubers is a physiological disorder which in its final state results in totally hollow tubers. Recordings over a period of some months on Dutch vegetable auctions indicated that sponginess of radish roots is a very serious problem. From the recordings it was obvious that environmental factors such as day temperature and humidity might promote or delay the occurrence of sponginess.

Takano (1963, 1966a, 1966b), Hagiya (1952) and Fujimura (1957) state that sponginess in radish roots occurs when the plants ripen and the tubers grow rapidly in thickness. Then, according to Takano (1966), accumulation of assimilates or nutritives in the tuber lags behind the sudden increase of volume of the tuber due to the abrupt thickening growth; this discrepancy might cause sponginess.

Though quite a number of observations on sponginess have been published, still very little is known about the specific growing conditions causing the incidence of sponginess in radish. Besides humidity, the two most suspected cultural conditions are day temperature and salt concentration in the soil, as the former affects plant development rate and transpiration, and the latter vegetative growth. The influence of these two factors on the degree of sponginess was studied in two experiments. 
The experimental conditions were such that they could be changed during development of the plants. In this way the effect of the factors tested could be evaluated with respect to the stage of development of the tubers.

\section{Materials and methods}

Two experiments were conducted in greenhouses of the Glasshouse Crops Research Station at Naaldwijk during 1986 and 1987. In the first experiment sponginess in radish was studied with cv. Novired. On 28 January 1986 seeds were sown in 101 buckets filled with commercial potting substrate. Per bucket, 14 plants were maintained, which corresponds to a plant density of 200 plants per $\mathrm{m}^{2}$.

Water and nutrients were applied via trickle irrigation during daytime hours, the nutrient solution being maintained at three different concentrations, viz. electrical conductivities (EC) of 1,4 and $8 \mathrm{dS} \mathrm{m}^{-1}\left(25^{\circ} \mathrm{C}\right)$. The salt concentrations were achieved by dissolving calcium nitrate and Nutriflora $T$, forming a complete nutrient solution. The composition of the nutrient solution was: $\mathrm{N} 6.12, \mathrm{P} 0.63, \mathrm{~K}$ 3.49, Mg 0.51, S 1.54 and Ca $2.37 \mathrm{mmol}^{-1}$; Fe 5.12, Mn 9.69, B 14.91, Zn 1.88, Mo 0.30 and $\mathrm{Cu} 0.13 \mu \mathrm{mol} \mathrm{l}^{-1}$. Water and nutrient supply amounted to ca $100 \mathrm{ml}$ per hour for each bucket. Temperature in one compartment of the greenhouse was set at $5 / 7{ }^{\circ} \mathrm{C}$ (night/day), in the other at $5 / 12{ }^{\circ} \mathrm{C}$ (night/day). Forty-five days after sowing, in the tuber formation stage (diameter of the tuber ca $3 \mathrm{~mm}$ ), five buckets from the higher EC treatment were transferred to lower EC and vice versa, so that in the second phase of the experiment, $9 \mathrm{EC}$ treatments were obtained.

Moreover, from each EC combination, buckets were transferred from one compartment $\left(5 / 7{ }^{\circ} \mathrm{C}\right)$ to the other $\left(5 / 12^{\circ} \mathrm{C}\right)$. On 27 and 29 March and 4 April 1986, 1, 2 and 2 buckets were harvested, respectively.

In the second experiment $\mathrm{cv}$. Novired was sown on 4 December 1986. The temperature was set at $5 / 10^{\circ} \mathrm{C}$ (night/day). The $\mathrm{EC}$ treatments were 1 and $8 \mathrm{dS} \mathrm{m} \mathrm{m}^{-1}$ $\left(25^{\circ} \mathrm{C}\right)$, maintained continuously during the growing period. Two, four, six, seven and eight weeks after sowing, the buckets were switched from low EC to high EC and vice versa. The total number of combinations thus became 12 in eight replicates. Every replicate consisted of one bucket. Plant density was the same as in the first experiment, i.e. 200 plants per $\mathrm{m}^{2}$. Harvesting of the radish plants was done on 18 February 1987.

In the two experiments, leaf length, tuber diameter and the degree of sponginess were observed. Sponginess was determined according to a scale from $1-10$ in which $1=$ completely hollow and $10=$ free from sponginess.

\section{Results}

The temperatures observed during the growing period in both experiments deviated not more than $0.5{ }^{\circ} \mathrm{C}$ from the setpoints. Table 1 shows the mean values of sponginess at three successive harvests in the first experiment. A later harvest date and continuous higher day temperature resulted in more serious symptoms of sponginess; also higher salt concentrations reduced the incidence of sponginess 
Table 1. Mean value of sponginess (scale $1-10: 1=$ completely hollow, $10=$ free from sponginess) of radish at three harvest dates and two temperature regimes $\left(5 / 7^{\circ} \mathrm{C}=\mathrm{L} ; 5 / 12{ }^{\circ} \mathrm{C}=\mathrm{H}\right)$.

\begin{tabular}{llll}
\hline Harvest date & L & H & Mean \\
27 March 1987 & 8.26 & 7.52 & 7.89 \\
29 March 1987 & 7.49 & 6.79 & 7.14 \\
4 April 1987 & 6.39 & 5.80 & 6.09 \\
Mean & 7.38 & 6.70 & 7.04 \\
\hline
\end{tabular}

(Table 2). The effects of the EC level in the period before and during tuber growth are presented in Table 2. Above an EC level of $4 \mathrm{dS} \mathrm{m}^{-1}$ after the start of tuber formation $\left(\mathrm{EC}_{2}\right)$ no significant decrease in sponginess on either harvest date and in either temperature treatment could be found. An interaction between EC level and day temperature could not be observed. Furthermore, the results in Table 2 demonstrate an increase in sponginess with later harvest dates.

Plants grown at a day temperature of $7{ }^{\circ} \mathrm{C}$ had on average $4 \%$ shorter leaves and a $6 \%$ smaller diameter of the tubers than those in the $12^{\circ} \mathrm{C}$ treatment. The average percentage of spongy tubers at low and at high day temperature was 23 and 32 , respectively.

Table 2. The effect of the $\mathrm{EC}$ level before $\left(=\mathrm{EC}_{1}\right)$ and after start $\left(=\mathrm{EC}_{2}\right)$ of radish tuber growth on the mean value of sponginess at three harvests.

\begin{tabular}{lllll}
\hline $\mathrm{EC}_{1}$ & \multicolumn{1}{c}{$\mathrm{EC}_{2}$} & & & \\
& 1 & 4 & 8 & mean \\
27 March & & & & \\
1 & 6.40 & 7.39 & 7.64 & 7.15 \\
4 & 7.25 & 8.07 & 7.98 & 7.77 \\
8 & 7.94 & 8.92 & 9.35 & 8.76 \\
mean & 7.22 & 8.13 & 8.32 & 7.89 \\
29 March & & & & \\
1 & 5.51 & 6.91 & 7.04 & 6.49 \\
4 & 6.42 & 7.31 & 7.39 & 7.04 \\
8 & 6.99 & 8.16 & 8.62 & 7.92 \\
mean & 6.31 & 7.43 & 7.68 & 7.14 \\
4 April & & & & \\
1 & 4.72 & 4.96 & 5.55 & 5.08 \\
4 & 4.98 & 6.40 & 7.33 & 6.23 \\
8 & 5.12 & 7.51 & 8.28 & 6.97 \\
mean & 4.94 & 6.29 & 7.05 & 6.09 \\
\hline
\end{tabular}


degree of sponginess

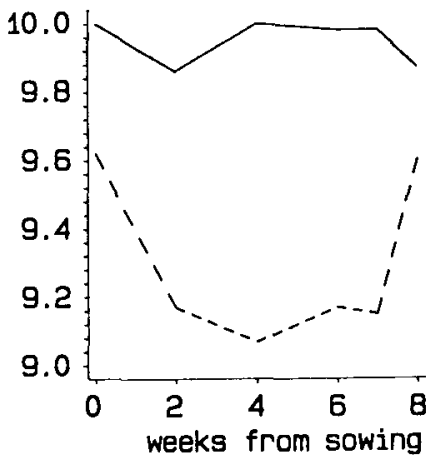

Fig. 1. Effects of the EC of the nutrient solution applied in various stages of growth on the incidence of sponginess in radish tubers: - switch from EC 1 to EC 8,--- switch from EC 8 to EC 1 .

The effect of changing the EC levels on sponginess in the second experiment is shown in Fig. 1. The constant EC levels $\left(1\right.$ and $\left.8 \mathrm{dS} \mathrm{m}^{-1}\right)$ can be compared each with ECs switched from 1 to $8 \mathrm{dS} \mathrm{m}^{-1}$, and vice versa, in the 2nd, 4th, 6th, 7th and 8 th week after sowing. The observations clearly point out that a switch from low to high EC level prevents the occurrence of sponginess, whereas a switch from high to low $\mathrm{EC}$ results in an increased incidence of sponginess.

\section{Discussion and conclusions}

In the first experiment it is shown that by a lower day temperature, sponginess decreases. The effect of EC on the degree of sponginess is evident and more or less the same for the period before tuber growth $\left(E C_{1}\right)$ and the period of tuber growth $\left(\mathrm{EC}_{2}\right.$; Table 2$)$, since no interaction between $\mathrm{EC}_{1}$ and $\mathrm{EC}_{2}$ could be found. Postponing the harvest with 8 days decreased the mean value of sponginess with about $23 \%$. Only for the first harvest, the effect of salt in the second period seems less obvious. From the second experiment, with a more precise timing of changing the ECs, it is clear that higher salt concentrations significantly restrict the formation of spongy tissue, irrespective of the stage of growth at which the higher EC was applied until 7 weeks after sowing (Fig. 1). At 8 weeks after sowing, tubers were probably spongy already. The same applies in the opposite way to the noxious effect of applying a low EC. A reduced temperature results in a lower growth rate and decreased transpiration, consequently in a reduced incidence of sponginess. A higher EC level shows the same results. On the basis of the data obtained it is possible to distinguish between temperature and EC effects.

These experimental data indicate possibilities to improve radish tuber quality (prevention of sponginess) by a higher nutrient concentration. Growing at somewhat lower daytime temperatures is also promising. 


\section{References}

Fujimura, T., 1957. Studies on the pithiness of root vegetables. 1. On the anatomical observation for the process of pithiness in radish roots. Studies of the Institute for Horticulture, Kyoto University 8: 81-85.

Hagiya, K., 1952. Physiological studies on the occurrence of the pithy tissue in root crops. 1. On the process of the occurrence of pithy tissue in company with the growth of radish. Journal of the Horticultural Association of Japan 21:81-86.

Takano, T., 1963. Studies on the pithiness of radish. I. Relationship between the degree of pithiness and organic constituents in radish root. Journal of the Japanese Society for Horticultural Science 32: 38-43.

Takano, T., 1966. Studies on the pithiness of radish. IV. On the process of pithy tissue formation in radish root. Journal of the Japanese Society for H rticultural Science 35: 152-157.

Takano, T., 1966. Studies on the pithiness of radish. VI. The effect of soil and fertilizer on the pithy tissue formation. Journal of the Japanese Society for Horticultural Science 35: 400-403. 